\title{
Flora da Bahia: Eugenia sect. Eugenia (Myrtaceae)
}

\author{
Karoline Coutinho $^{1^{*}}$, Marla Ibrahim Uehbe de Oliveira, ${ }^{2, a}$, Fiorella Fernanda Mazine ${ }^{3, b}$ \& Ligia Silveira \\ Funch ${ }^{1, c}$
}

${ }^{1}$ Programa de Pós-graduação em Botânica, Departamento de Ciências Biológicas, Universidade Estadual de Feira de Santana, Feira de Santana, Bahia, Brasil.

2 Departamento de Biologia, Centro de Ciências Biológicas e da Saúde, Universidade Federal de Sergipe, Sergipe, Brasil.

${ }^{3}$ Universidade Federal de São Carlos, campus de Sorocaba, Sorocaba, São Paulo, Brasil.

\begin{abstract}
Resumo - É apresentada a flora de Eugenia sect. Eugenia para o estado da Bahia. São reconhecidas 17 espécies; é apresentada uma chave de identificação, bem como descrições, ilustrações, comentários e mapas de distribuição geográfica das espécies no estado.

Palavras-chave adicionais: Caatinga, Cerrado, Floresta Atlântica, taxonomia.
\end{abstract}

\begin{abstract}
Flora of Bahia: Eugenia sect. Eugenia (Myrtaceae)) - The flora of Eugenia sect. Eugenia from the state of Bahia, Brazil, is presented. Seventeen species are recognized; an identification key, descriptions, illustrations, comments and maps of their geographic distribution in the state are provided.
\end{abstract}

Additional key words: Atlantic Forest, Caatinga, Cerrado, taxonomy.

Myrtaceae agrupa aproximadamente 5.500 espécies e 144 gêneros, distribuídos sobretudo nas zonas tropical e subtropical, com os principais centros de diversidade na região Neotropical, na Austrália e no sudeste da Ásia (Wilson et al. 2005; Govaerts et al. 2008; Wilson 2011; WCSP 2017). No Brasil, ocorrem 1.018 espécies e 23 gêneros de Myrtaceae, e na Bahia, 16 gêneros e 304 espécies (Flora do Brasil 2020). A família pode ser facilmente reconhecida pelas folhas opostas, inteiras, com glândulas de óleo, e pelas flores tetrâmeras ou pentâmeras, geralmente com numerosos estames e ovário ínfero a semi-ínfero; além disso, apresentam floema interno e pontuações guarnecidas nos vasos do xilema (para uma descrição formal da família, veja Oliveira et al. 2012).

As Myrtaceae estão subdivididas em duas subfamílias: Psiloxyloideae, com duas tribos, e Myrtoideae, com 15, destacando-se Myrteae, tribo que engloba as mirtáceas neotropicais, exceto Metrosideros stipularis (Hook. \& Arn.) Hook. f., que pertence a tribo Metrosidereae (Wilson et al. 2005; Lucas et al. 2007). Myrteae se distingue dentre as Myrtoideae pelos frutos carnosos e sistema vascular transeptal (Wilson et al. 2005; Lucas et al. 2007). A tribo compreende 49 gêneros e cerca de 2.500 espécies, incluindo os grandes gêneros Eugenia L. e Myrcia DC. ex. Guill. (Lucas et al. 2007).

\section{Eugenia L.}

Árvores, arbustos ou subarbustos. Inflorescências em racemos, dibótrios, botrioides, dicásios ou flores

\footnotetext{
*Autora para correspondência: karolinecoutinho@yahoo.com.br; amarlauehbe@yahoo.com.br; bfiorella@ufscar.br;

cligiafunch@yahoo.com

Editor responsável: Alessandro Rapini

Submetido: 6 nov. 2017; aceito: 28 dez. 2017

Publicação eletrônica: 29 dez. 2017; versão final: 14 abr. 2018
}

isoladas, terminais, laterais ou axilares nos ramos velhos, ou raramente cauliflora, com antopódio; brácteas livres, persistentes ou caducas; botões florais abertos. Flores geralmente tetrâmeras; estames numerosos; hipanto não prolongado acima do ovário; ovário geralmente bilocular, com poucos a numerosos óvulos por lóculo. Frutos bagas, alaranjadas, amarelas, vermelhas, atropurpúreas, até pretas quando maduras, com cálice persistente; sementes 1-3, embrião e cotilédones globosos, carnosos, fundidos em uma massa sólida, com linha de separação entre os cotilédones; eixo hipocótilo-radícula pouco desenvolvido.

Eugenia é o maior gênero neotropical de Myrtaceae, compreendendo 1.108 espécies (WCSP 2017), distribuídas do sul do México e Caribe até o norte da Argentina, com poucas espécies ocorrendo na África e sudeste asiático e no Pacífico (Wilson 2011). Berg (1855-1857) dividiu o gênero em oito seções com base no tipo de inflorescência, as quais não se mostraram monofiléticas e foram redefinidas com base em oito clados, recuperados a partir de análises filogenéticas com dados moleculares (Mazine et al. 2014). Dentre as oito seções de Eugenia, a sect. Eugenia corresponde ao gênero Stenocalyx O.Berg e a seção Stenocalyx Nied. (Mazine et al. 2016).

\section{Eugenia sect. Eugenia}

Árvores, arbustos ou subarbustos. Folhas membranáceas a coriáceas, margens pouco revolutas (exceto em E. brasiliensis); estípulas ausentes. Flores tetrâmeras, em racemos autotélicos terminais ou axilares; brácteas e bractéolas decíduas ou persistentes após antese; lobos do cálice individualizados, 3-7 mm compr.; lóculos do ovário com paredes internas glabras e número de óvulos variável (1 a 20); sementes 1-3. 
A seção é constituída por cerca de 30 espécies, a maioria restrita ao Brasil, distribuídas por todo o país, mas concentradas no Nordeste, Centro-Oeste, Sudeste e Sul. É caracterizada por lobos do cálice compridos, proporcionalmente maiores que as flores, e brácteas foliáceas na base dos racemos e pedicelos. Nesta seção, o eixo da inflorescência volta a produzir folhas após a desenvolvimento das flores, formando racemos auxotélicos (Briggs \& Jonhson 1977).

\section{Chave para as espécies}

1. Hipanto costado.

2. Ramos jovens pilosos ou puberulentos; folhas com lâmina estreito-elíptica ou oblonga, pubérula na face adaxial, com nervura central levemente saliente na face adaxial e duas nervuras intramarginais

12. E. pitanga

2'. Ramos jovens glabros; folhas com lâmina lanceolada, ovada ou elíptica, glabra na face adaxial, com nervura central impressa na face adaxial e apenas uma nervura intramarginal

17. E. uniflora

1'. Hipanto liso.

3. Folhas com venação acródroma.

4. Folhas sésseis

15. E. sessilifolia

4'. Folhas pecioladas.

5. Ramos jovens glabros.

6. Folhas com ápice acuminado e base arredondada; lobos do cálice $\leq 3 \mathrm{~mm}$ compr.; disco estaminal ca. $1 \mathrm{~mm}$ diâm., puberulento .......................................................... 11. E. pistaciifolia

6'. Folhas com ápice arredondado ou agudo e retuso e base aguda ou cuneada; lobos do cálice $\geq 3,2$ mm compr.; disco estaminal ca. $3 \mathrm{~mm}$ diâm., piloso

10. E. piresii

5'. Ramos jovens com indumento.

7. Folhas com nervura intramarginal; brácteas naviculadas ou involucradas; disco estaminal $\geq 4 \mathrm{~mm}$ diâm.

1. E. brasiliensis

7'. Folhas sem nervura intramarginal; brácteas côncavas; disco estaminal $\leq 3,5 \mathrm{~mm}$ diâm.

8. Catafilos pilosos ou velutinos; lobos do cálice com tufo de tricomas no ápice ...... 8. E. ligustrina

8'. Catafilos glabros ou puberulentos; lobos do cálice sem tufo de tricomas no ápice.

9. Folhas glabras na face adaxial; pecíolo $\geq 3 \mathrm{~mm}$ compr.; lobos do cálice iguais; disco estaminal ca. $3 \mathrm{~mm}$ diâm. ................................................................ 14. E. potiraguensis

9'. Folhas pubérulas na face adaxial; pecíolo $\leq 1,5 \mathrm{~mm}$ compr.; lobos do cálice desiguais; disco estaminal ca. $2 \mathrm{~mm}$ diâm.

13. E. plicata

3'. Folhas com venação broquidódroma.

10. Folhas com menos de 10 pares de nervuras secundárias.

11. Folhas onduladas; frutos piriformes

4. E. duarteana

11'. Folhas planas; frutos globosos.

12. Lobos do cálice no botão com tufo de tricomas no ápice; disco estaminal $\leq 2,7 \mathrm{~mm}$ diâm.

5. E. dysenterica

12'. Lobos do cálice no botão sem tufo de tricomas no ápice; disco estaminal $\geq 3,2 \mathrm{~mm}$ diâm.

13. Folhas glabras, com ápice acuminado, sem tufo de tricomas, margens inteiras e nervura central plana na face adaxial

7. E. laxa

13'. Folhas pilosas, com ápice arredondado ou obtuso, raramente agudo, com tufo de tricomas, margens ciliadas e nervura central sulcada na face adaxial ...... 3. E. coccinea

10'. Folhas com mais de 10 pares de nervuras secundárias.

14. Ramos adultos puberulentos; folhas com nervura central saliente na face adaxial

4'. Ramos adultos glabros; folhas com nervura central sulcada na face adaxial.

15. Folhas com nervura intramarginal $1-2 \mathrm{~mm}$ distante da margem; pecíolo $\geq 8 \mathrm{~mm}$ compr., glabro

16. E. subreticulata

15'. Folhas com nervura intramarginal ausente ou menos de $1 \mathrm{~mm}$ distante da margem; pecíolo $\leq 5 \mathrm{~mm}$ compr., pubescente ou puberulento.

16. Ramos jovens pilosos; folhas com pecíolo $\leq 2 \mathrm{~mm}$ compr., pubescente, e lâmina membranácea, com nervuras secundárias curvadas e sem nervura intramarginal; lobos do cálice $\leq 3 \mathrm{~mm}$ compr., iguais; hipanto pubescente ............ 6. E. funchiana

16'. Ramos jovens puberulentos; folhas com pecíolo $\geq 2.1 \mathrm{~mm}$ compr., puberulento, e lâmina cartácea, com nervuras secundárias retas e nervura intramarginal mais externa menos de $1 \mathrm{~mm}$ distante da margem; lobos do cálice $\geq 4 \mathrm{~mm}$ compr., desiguais; hipanto seríceo 
1. Eugenia brasiliensis Lam., Encycl. 3: 203. 1789.

Figuras 1 e $6 \mathrm{~A}-\mathrm{C}$.

Árvores ou arbustos 2,2-20 m alt.; ramos jovens acastanhados, puberulentos, tricomas canescentes. Catafilos 2-7 × 2-4,5 mm, deltoides ou elípticos, ciliados, pilosos, ápice arredondado. Folhas com pecíolo 3,2-9,6 mm compr., glabro; lâmina 5,7-12,5 × 3,9-2,6 cm, cartácea, elíptica ou obovada, plana, pouco reticulada, pubérula em ambas as faces, raramente pilosa quando jovem, pontuações translúcidas impressas (não visíveis a olho nu), ápice acuminado, base aguda, margens pouco revolutas; venação acródroma, nervura central sulcada na face adaxial, saliente na abaxial, glabra, 16-22 pares de nervuras secundárias, glabras, ascendentes, pouco visíveis na face abaxial, todas confluentes com a intramarginal, 2 nervuras intramarginais de cada lado, a mais interna 1$3 \mathrm{~mm}$ distante da margem, a mais externa $0,4-0,7 \mathrm{~mm}$ distante da margem. Inflorescências com 1-4 flores; pedicelos 2,6-3,5 cm compr., glabros; brácteas 0,6-2,7 $\mathrm{cm}$ compr., elípticas, naviculadas ou involucradas, ápice arredondado, pilosas na face externa. Flores com lobos do cálice desiguais, os maiores $6-7 \times 3,5-4 \mathrm{~mm}$, os menores 4-5 × 2-3 mm, deltoides ou oblongos, inteiros, face externa pubérula, ápice agudo, tricomas canescentes; pétalas 0,9-1,2 × 0,4-0,6 mm, ovadas, glabras, revolutas, ápice arredondado, glandulosas; disco estaminal ca. 4 mm diâm., piloso; estames ca. 50, $3,2-5 \mathrm{~mm}$ compr.; hipanto $2-3 \times 1,9-2,8 \mathrm{~mm}$, liso, piloso, glanduloso. Frutos ca. $2 \times 2 \mathrm{~cm}$, lisos, globosos, verrucosos, atropurpúreos, glabros, com pontuações; semente 1 , ca. $1,3 \times 1 \mathrm{~cm}$, glandulosa.

Eugenia brasiliensis é exclusiva da Mata Atlântica, ocorrendo de Santa Catarina a Bahia (Sobral et al. 2017). F7, F8, G8, H8 e I8: em florestas ombrófilas, matas higrófilas e restingas. Foram encontrados, também, três espécimes em área de caatinga, associados a áreas antropizadas, possivelmente cultivadas pelos frutos comestíveis in natura (Lorenzi et al. 2006; Souza \& Morim 2008). A floração ocorre de setembro a março e a frutificação entre janeiro e março.

Material selecionado - Aurelino Leal, $14^{\circ} 19^{\prime} 59^{\prime \prime} \mathrm{S}, 39^{\circ} 22^{\prime} 00^{\prime} \mathrm{W}$, out. 2001 (fl.), Thomas et al. 12678 (CEPEC); Caravelas, 1742'56”S, 39॰11'55”'W, dez. 2011 (fl.), Matos-Silva 1281 (HUEFS); Ilhéus, $14^{\circ} 48^{\prime} \mathrm{S}, 39^{\circ} 10^{\prime} \mathrm{W}$, out. 2001 (fl.), Matos-Silva 4501 (CEPEC, HUEFS); Itacaré, 14022'50”S, 39002'23”'W, dez. 2011 (fl.), Lacerda 235 (CEPEC); Ituberá, $13^{\circ} 43^{\prime} \mathrm{S}, 39^{\circ} 08^{\prime} \mathrm{W}$, set. 2001 (bot.), Guedes et al.

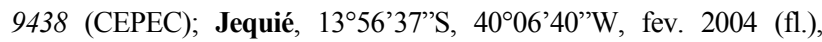
Thomas et al. 13866 (CEPEC); Lauro de Freitas, mar. 1984 (fl.), Pinto

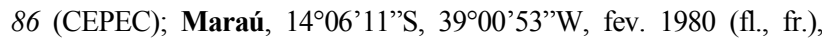

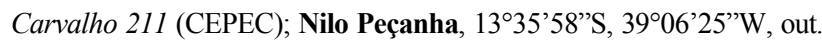
1984 (fl.), Mattos-Silva 1793 (EBDA); Porto Seguro, 16²6’58”S, 39॰03'53”'W, out. 1971 (fl.), Lima 12715 (CEPEC, HUEFS); Santa

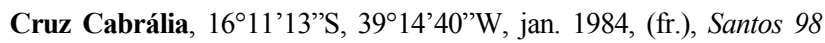

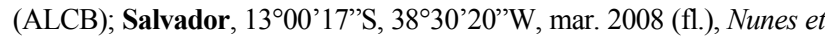
al. 74 (ALCB); Una, 1509'S, 3905’W, nov. 1993 (fl.), Amorim 1431 (CEPEC); Venda Nova $20^{\circ} 20^{\prime} 23^{\prime}$ 'S, $41^{\circ} 08^{\prime} 05^{\prime}$ W, nov. 1986 (fl.), Soares-Silva 1998 (INPA).
Eugenia brasiliensis pode ser reconhecida pelas folhas elípticas, com nervuras secundárias e intramarginais evidentes na face adaxial. Além disso, o tamanho (0.6-2.7 cm compr.) associado à forma (elípticas, naviculadas ou involucradas) de suas brácteas permite diferenciá-la das demais espécies da seção. Eugenia coccinea, por exemplo, possui brácteas de $0,7-0,9 \mathrm{~cm}$ de comprimento, se sobrepondo às de E. brasiliensis, porém apresentam forma diferente linear.

\section{Eugenia caatingicola K.Cout. \& M.Ibrahim,} Phytotaxa 234(3): 216. 2015.

Figuras 1 e $6 \mathrm{D}-\mathrm{F}$.

Árvores ca. $4 \mathrm{~m}$ alt.; ramos jovens acastanhados, com tricomas canescentes esparsos. Catafilos não vistos. Folhas com pecíolo $2-5 \mathrm{~mm}$ compr., canaliculado, pubérulo; lâmina 2,5-7 × $1-2,5 \mathrm{~cm}$, cartácea, lanceolada ou ovada, raro obovada, plana, reticulada, com pontuações translúcidas em ambas as faces, ápice agudo, retuso, base cuneada ou arredondada, margens pouco revolutas, onduladas; venação broquidódroma, nervura central sulcada na face adaxial, saliente na abaxial, com tricomas canescentes, 13-20 pares de nervuras secundárias, glabras, ascendentes, todas confluentes com a intramarginal, 2 nervuras intramarginais de cada lado, a mais interna $1,8-3 \mathrm{~mm}$ distante da margem, a mais externa $0,3-0,4 \mathrm{~mm}$ distante da margem. Inflorescências com 2-4 flores; pedicelos 1,5-2,9 cm compr., pubescentes; brácteas e bractéolas não vistas. Flores com lobos do cálice desiguais, os maiores ca. 6 $\times 4 \mathrm{~mm}$, os menores ca. $5 \times 4 \mathrm{~mm}$, oblongos ou deltoides, ciliados, pubescentes, glandulosos, ápice arredondado; pétalas 7-9 × 4-5 $\mathrm{mm}$, clavadas ou espatuladas, ciliadas, face externa pubescente, ápice cuneado ou arredondado, glandulosas; disco estaminal ca. 4 mm diâm., pubescente; estames não contados, 56,5 mm compr., glabros; hipanto 3,8-4,3 × 4,4-5,2 mm compr., liso, seríceo. Frutos globosos, castanhos, seríceos, eglandulosos; sementes não vistas.

Eugenia caatingicola está restrita ao Piauí e à Bahia. E7: em caatinga, com frutos em janeiro.

Material examinado - Ruy Barbosa, $12^{\circ} 18^{\prime} 09^{\prime \prime} \mathrm{S}$, 40²9’16”W, jan. 2006 (fr.), Queiroz \& Cardoso 12045 (HUEFS).

Material adicional - BRASIL. PIAUÍ: Serra das Confusões, 09॰09'52”S, 43²3'04”W, nov. 2010 (fl.), Mello et al. 8831 (HUEFS).

Eugenia caatingicola assemelha-se a $E$. subreticulata pelas folhas lanceoladas ou ovadas, cartáceas, reticuladas, com 2,5-7 cm de comprimento, diferenciando-se pelo ápice foliar retuso (vs. agudo) e hipanto seríceo (vs. glabro).

3. Eugenia coccinea K.Cout. \& M.Ibrahim, Phytotaxa 234(3): 220. 2015.

Figuras 1 e $8 \mathrm{P}-\mathrm{R}$.

Árvores ou arbustos 2-3 m alt.; ramos jovens acastanhados, pilosos, tricomas acastanhados. 
Catafilos 1-1,5 × 1-1,2 mm, rotundos, pubescentes, ápice arredondado. Folhas com pecíolo 2-6 mm compr., canaliculado, pubescente; lâmina 2-6,4 × 0,9-3,4 cm, membranácea, obovada, elíptica ou lanceolada, plana, reticulada, pilosa e glandulosa em ambas as faces, ápice arredondado, obtuso ou raramente agudo, com um tufo de tricomas castanhos, base aguda ou cuneada, margens ciliadas, onduladas e pouco revolutas; venação broquidódroma, nervura central sulcada na face adaxial, saliente na abaxial, tomentosa, com tricomas canescentes na face adaxial, ferrugíneos na abaxial, ápice com um tufo de tricomas ferrugíneos, 5-9 pares de nervuras secundárias, ascendentes, tomentosas, sem nervuras intramarginais. Inflorescências com 2 flores; pedicelos 3-3,5 cm compr., glandulosos; brácteas lineares $0,7-0,9 \mathrm{~mm}$, ápice agudo, pubescente, tricomas acastanhados; bractéolas não vistas. Flores com lobos do cálice desiguais, $0,5-0,7 \times 0,3-0,5 \mathrm{~cm}$, deltoides ou oblongos, ciliados, ápice arredondado, cuneado, pubescentes em ambas as faces, glandulosos; pétalas 8 $11 \times 5-8 \mathrm{~mm}$, clavadas, ciliadas, com poucos tricomas na face externa, ápice arredondado, com poucas glândulas; disco estaminal ca. $4 \mathrm{~mm}$ diâm., piloso; estames ca. 70, 3,5-6 mm compr.; hipanto 1,7-2,1 $\times$ 1,5-1,7 mm, liso, glabro ou com raros tricomas, glanduloso. Frutos e sementes não vistos.

Eugenia coccinea parece ser endêmica da Bahia. F7: em caatinga, com flores em outubro.

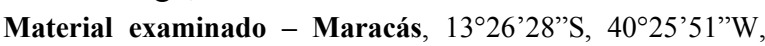
out. 1983 (fl.), Carvalho 1983 (CEPEC, MBM, SP).

Eugenia coccinea assemelha-se a $E$. duarteana por apresentar folhas obovadas com nervuras tomentosas e lobos do cálice indumentados. Entretanto, E. coccinea apresenta folhas membranáceas (vs. coriáceas) e hipanto glabro (vs. tomentoso); além disso, possui

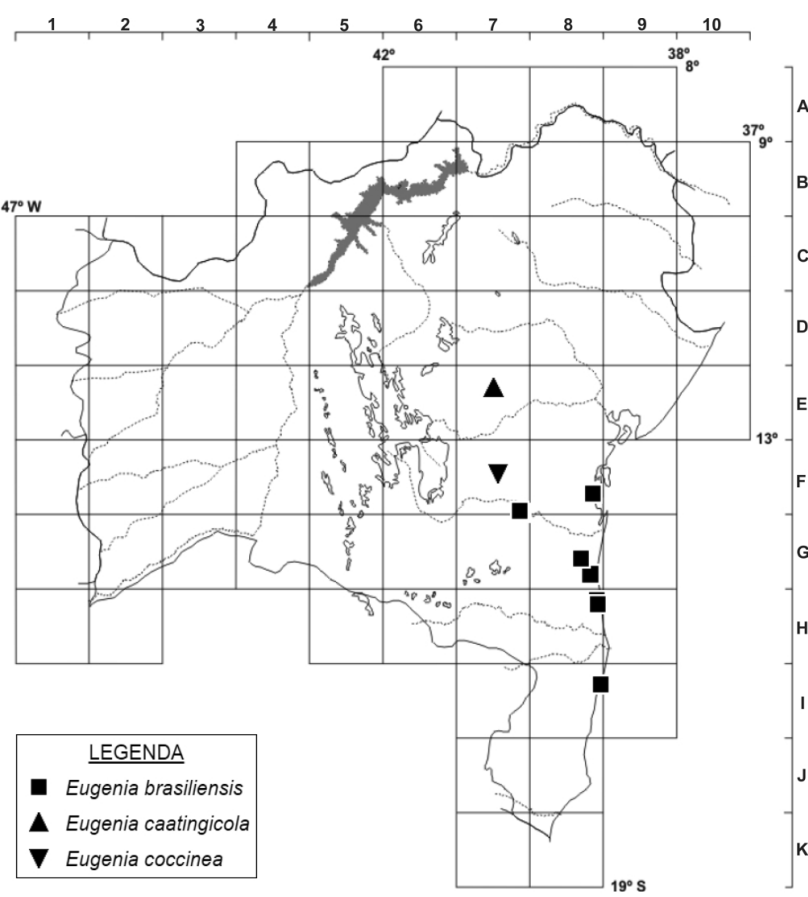

Figura 1. Mapa de distribuição de Eugenia brasiliensis, E. caatingicola e E. coccinea no estado da Bahia. folhas com um tufo de tricomas ferrugíneos no ápice da nervura central e margens ciliadas.

4. Eugenia duarteana Cambess. in Saint-Hilaire, Fl. Bras. Merid. (quarto ed.) 2: 348. 1832.

Figuras 2 e 6G-I.

Arbustos ou arvoretas 2,5-4 m alt.; ramos jovens castanho-escuros, tomentosos, tricomas canescentes, castanhos. Catafilos não vistos. Folhas com pecíolo 0,1-5 mm compr., canaliculado, pubescente, tricomas castanhos; lâmina 2,2-4,5 × 0,6-2,6 cm, coriácea, obovada, ondulada, reticulada, pubérula em ambas as faces, glândulas não evidentes, ápice obtuso a arredondado, base aguda a cuneada, margens pouco revolutas, face adaxial opaca; venação broquidódroma, nervura primária tomentosa, sulcada na face adaxial, com glândulas proeminentes na abaxial, 6-8 pares de nervuras secundárias, ascendentes, pilosas, tricomas canescentes, castanhos, sem nervuras intramarginais. Inflorescências com 2-6 flores; pedicelos 8-10 mm compr., puberulentos; brácteas 0,6-0,7 mm compr., espatuladas ou naviculadas, ciliadas, tomentosas, ápice agudo; bractéolas ausentes. Flores com lobos do cálice iguais, 3,4-4 mm compr., pubérulos a pubescentes; pétalas 4,7-7,3 $\mathrm{mm}$, obovadas, convexas, glabras, ciliadas, eglandulosas; disco estaminal 1,8-2,7 $\mathrm{mm}$ diâm., pubescente; estames não contados, 5,5-8 mm; hipanto $1,7-2 \times 1,4-1,7 \mathrm{~mm}$, liso, tomentoso, glândulas não vistas. Frutos 1,4-2,1 × 1-1,7 cm, lisos, glândulas pouco salientes, verdes quando imaturos, pubérulos ao menos na base; sementes não vistas.

Eugenia duarteana ocorre em Minas Gerais, Piauí e Bahia (Flora do Brasil 2020). D6: em áreas de caatinga, com flores e frutos em janeiro.

Material examinado - Morro do Chapéu, $11^{\circ} 33^{\prime} \mathrm{S}$, 4109’33”W, jan. 2012 (fl., fr.), Carvalho-Sobrinho 3214 (HUEFS).

Eugenia duarteana difere das demais espécies da seção por apresentar folhas pubescentes e flores tomentosas, com tricomas canescentes a castanhos, e frutos piriformes.

5. Eugenia dysenterica DC., Prodr. 3: 268. 1828.

Figuras 2 e 6J, K.

Árvores ou arbustos 2-7 m alt.; ramos jovens ferrugíneos, glabros, raramente com alguns tricomas ou pubérulos. Catafilos 1,5-3 × 1-3 mm, côncavos, ovados, pubérulos a glabrescentes externamente, ciliados, ápice arredondado ou acuminado. Folhas com pecíolo 1,4-5 mm compr., canaliculado, glabro; lâmina 3-10.5 × 1.6-6.3 cm, cartácea, elíptica ou ovalada, plana, reticulada, glabra ou com tricomas canescentes esparsos e adpressos, glandulosa em ambas as faces, ápice obtuso ou agudo, base aguda, cuneada ou arredondada, margens onduladas; venação broquidódroma, nervura central sulcada na porção proximal e levemente saliente na distal da face adaxial, saliente na face abaxial, glabra ou com tricomas esparsos e adpressos, 8-10 pares de nervuras secundárias, glabras, ascendentes ou pouco curvadas, 
sem nervuras intramarginais. Inflorescências com 4-6 flores; pedicelos 1-2,5 cm compr., glabros ou pubérulos, tricomas canescentes; brácteas não vistas; bractéolas 1-2 mm compr., lineares, pilosas, tricomas simples, castanhos, ápice arredondado. Flores com lobos do cálice iguais, $2,5-4 \times 0,8-1,8 \mathrm{~mm}$, deltoides a ovados, ciliados, ápice agudo a arredondado, com um tufo de tricomas ferrugíneos; pétalas 5-9 5 4-8 mm, elípticas ou obovadas, ápice arredondado, inteiras ou ciliadas, glandulosas; disco estaminal 2,8-3 mm diâm, pubescente, estames $60-75,3-8 \mathrm{~mm}$ compr.; hipanto $1-2,5 \times 0,8-1,1 \mathrm{~mm}$, liso, glabro, glanduloso. Frutos 2,5-3 $\times 2-2,5 \mathrm{~cm}$, lisos, globosos, glabros, amarelos quando maduros, glandulosos; sementes $1-3,1-1,2 \times$ $0,6-0,9 \mathrm{~cm}$, glandulosas.

Eugenia dysenterica ocorre em São Paulo, Minas Gerais, Mato Grosso, Goiás, Distrito Federal, Tocantins, Bahia, Ceará, Maranhão, Pernambuco e Piauí (Flora do Brasil 2020). D2, D6, E2, F3, F5, G3, G4 e G5: em cerrados, caatingas, em transição entre caatinga e cerrado, e em campos rupestres. Floresce e frutifica entre maio e dezembro.

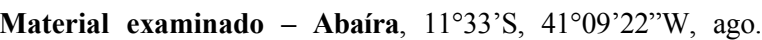
1992 (fl.), Ganev 875 (HUEFS); Barreiras, 12³0’59”S, 4505'42”W, jun. 2007 (fl.), Dânaso 5 (HUEFS); Caetité,

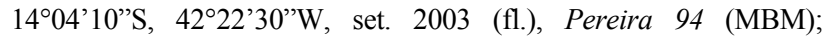

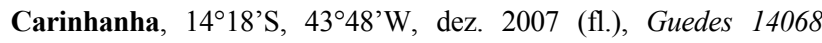

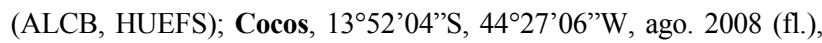

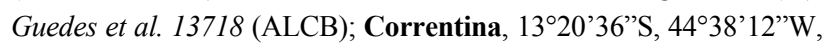
out. 1989 (fl.), Violatti 63 (RB); Érico Cardoso, 13¹9'50"S, 4205'54'W, jul. 2001 (fl.), Bautista 3259 (HUEFS); Feira da Mata, 14¹3'54'S, 44¹2'45”W, maio 2007 (fl., fr.), Guedes et al. 13419

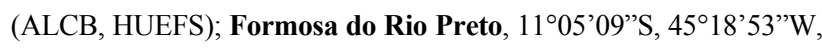
nov. 1997 (fr.), Silva 3592 (HUEFS); Itaberaba, 13²7’07'S, 4008'04”W, s.d. (fr.), Araújo 131 (RB); Luís Eduardo Magalhães, 1205'57’'S, 4546'10'W, set. 2003 (fl., fr.), Guedes et al. 10925 (ALCB); Macaúbas, 1301'10”S, 4241'55”W, dez. 2003 (fl.), Harley 54664 (HUEFS); Oliveira dos Brejinhos, 12 19’01'S, 42 53'46”'W, out. 1981 (fl.), Hatschbach 44179 (CEPEC); Piatã, set. 1992 (fl.), Ganev 1159 (HUEFS); 1303’39”'S, 4152’49”W, set. 2004 (f1.), Guedes et al. 11413 (ALCB); Rio de Contas, 13³4'32”S, 4149’32”W, set. 1996 (fl., fr.), Harley 28261 (HUEFS); Santa Maria da Vitória, 13²2'59”'S, 44³4'59”'W, jul. 2007 (fl., fr), Correia 268 (HUEFS); Tucano, 1055'56”'S, 38³8'13”'W, dez. 2004 (fl.), Cardoso 216 (HUEFS); Urandi, 1449’17’'S, 42³9'18’'W, nov. 2001 (fr.), Hatschbach 78707 (MBM).

Eugenia dysenterica distingue-se das demais espécies da seção pelo tronco com ritidoma espesso e textura escamosa, as nervuras bem evidentes em ambas as faces, os tufos de tricomas ferrugíneos no ápice do botão e os frutos grandes e amarelos quando maduros.

6. Eugenia funchiana K.Cout \& M.Ibrahim, Phytotaxa 234(3): 218. 2015.

Figuras 2 e $8 \mathrm{M}-\mathrm{O}$.

Árvores ca. $4 \mathrm{~m}$ alt.; ramos jovens acastanhados, pilosos. Catafilos $1-2,5 \times 1,1-1,3 \mathrm{~mm}$, ápice arredondado ou agudo, ciliados, pubescentes. Folhas com pecíolo 1-2 mm, canaliculado, pubescente; lâmina
1,6-2,4 $\times$ 0,8-1,3 cm, membranácea, ovada ou lanceolada, reticulada, plana, glabra ou pilosa, glandulosa (glândulas não visíveis a olho nu), ápice agudo, base cuneada, margens onduladas; venação broquidódroma, nervura central sulcada na porção proximal e impressa na porção distal da face adaxial, saliente na face abaxial, com poucos tricomas, 8-13 pares de nervuras laterais, curvadas, raramente subascendentes, glabrescentes, 1 nervura intramarginal formada pelas nervuras secundárias. Inflorescências 2-4 flores; pedicelos 1,3-1,5 cm compr., glabros; brácteas ca. 3,5 $\mathrm{mm}$ compr., espatuladas, pilosas, ápice agudo, glandulosas; bractéolas ausentes. Flores com lobos do cálice iguais, 2,5-2,9 × 1,1-1,2 mm, glabros, ciliados, ápice cuneado, glândulas não visíveis; pétalas 3,4-3,5 $\times \quad 0,8-0,9 \mathrm{~mm}$, espatuladas ou lineares, onduladas, ciliadas, ápice agudo ou arredondado, glabras, eglandulosas; disco estaminal 2,8-3 $\mathrm{mm}$ diâm., glabro; estames ca. 60, 1.9-3.4 mm compr.; hipanto $1,2-1,3 \times 1-1,2 \mathrm{~mm}$, liso, pubescente. Frutos e sementes não vistos.

Eugenia funchiana é endêmica da Bahia. C8: em caatinga, com flores em fevereiro.

Material examinado - Monte Santo, $10^{\circ} 27^{\prime} 00^{\prime \prime} \mathrm{S}$, 39²0’00’W, fev. 1974 (fl.), Harley 16431 (CEPEC, RB).

As folhas pequenas, com nervuras secundárias curvadas formando a nervura marginal, e pecíolo com tricomas apenas no dorso são características que tornam esta espécie diferente das demais desta seção. Assemelha-se a $E$. dentata (O.Berg) Nied., que não ocorre na Bahia, pela distribuição das folhas nos ramos, bem como pelo tamanho do pedicelo e das flores. Entretanto, E. funchiana possui folhas ovadas ou lanceoladas (vs. oblongo-lanceoladas ou oblongas em $E$. dentata), nervuras visíveis em ambas as faces

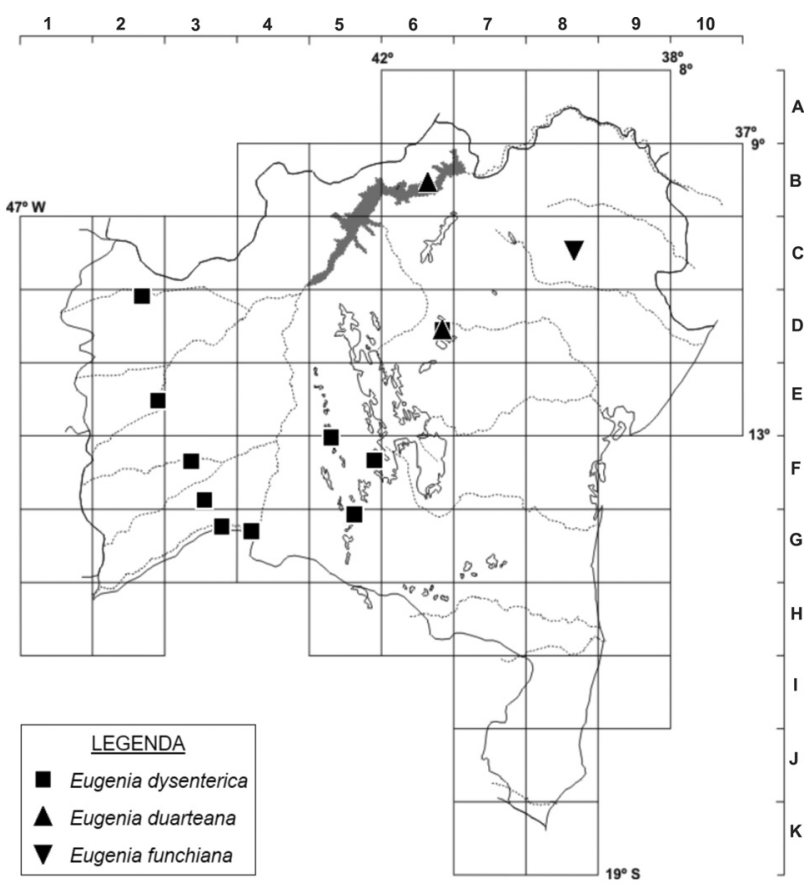

Figura 2. Mapa de distribuição de Eugenia duarteana, E. dysenterica e E. funchiana no estado da Bahia. 
(vs. não visíveis na face adaxial) e hipanto não costado e pubescente (vs. costado e glabro).

\section{Eugenia laxa DC., Prodr. 3: 263. 1828.}

Figura 3.

Árvores; ramos jovens bruneo-seríceos, os adultos acinzentados. Catafilos não vistos. Folhas com pecíolo 2-5 mm compr., bruneo-seríceo; lâmina 8-9 × 3,5-3,9, membranácea, oval-oblonga, plana, reticulada, glabra, glandulosa, ápice acuminado, assimétrico, base cuneada, margens inteiras; venação broquidódroma, nervura central plana na face adaxial, saliente na abaxial, pubérula, 3-6 nervuras secundárias, curvadas, visíveis em ambas as faces, glabras, formando a nervura marginal ca. $1 \mathrm{~cm}$ distante da margem, sem nervuras intramarginais. Inflorescências com 2-4 flores; pedicelos 3-3,5 cm compr., glabros. Flores não vistas. Frutos não vistos.

Eugenia laxa é endêmica da Bahia, conhecida apenas pelo tipo, coletado em Rio de Contas, na Chapada Diamantina. F6: coletada com frutos em janeiro.

Material examinado - "Habitat in silvaticis desertis ad Caiteté, Villam do Rio das Contas, in prov. Bahiensi”, s.d., Martius s.n. (holótipo M 0137751, foto!).

Eugenia laxa difere das demais espécies da seção principalmente pelas folhas com número reduzido de nervuras secundárias, que se curvam formando uma nervura marginal emarginada. Outra característica que chama a atenção nesta espécie é a assimetria das folhas próximo ao ápice. A descrição aqui apresentada teve como base a análise e mensuração da fotografia do tipo disponível no "Global plants" (JSTOR 2013) e nas descrições apresentadas por Candolle (1828) e Berg (1857-1859).

\section{Eugenia ligustrina (Sw.) Willd., Sp. P1. 2: 962.} 1799.

Figuras 3 e 6L-R.

Árvores ou arbustos 1,7-6 m alt.; ramos jovens acastanhados, pilosos, com tricomas canescentes, castanhos. Catafilos 2-5 $\times 2-3 \mathrm{~mm}$, oblongos, côncavos, ciliados, pilosos ou velutinos, ápice agudo. Folhas com pecíolo 2-4 $\mathrm{mm}$ compr., canaliculado, glabro ou pubescente; lâmina 1,4-5,7 × 0,4-2,1 cm, coriácea, elíptica, raro obovada ou ovada, plana, não reticulada, glabra ou pubérula, às vezes velutina na face adaxial quando jovens, muitas glândulas na face abaxial, poucas na adaxial, ápice agudo, acuminado ou retuso, base aguda ou cuneada, margens levemente revolutas; venação acródroma, nervura central sulcada na face adaxial, saliente na abaxial, às vezes não visível no ápice, glabra a pubescente, 9-19 pares de nervuras laterais, pouco visíveis em ambas as faces, glabras ou com poucos tricomas, todas confluentes com a nervura intramarginal distante $0,5-1,3 \mathrm{~mm}$ da margem. Inflorescências com 2-4 flores; pedicelos 0,3-1,4 cm compr., pilosos; brácteas 5,2-7 × ca. $4 \mathrm{~mm}$, lineares, glabras ou pubescentes na base e na face externa, ápice agudo, truncado ou arredondado; bractéolas ca. $5 \times 1 \mathrm{~mm}$, obovadas, ciliadas, glabras, glandulosa externamente, ápice truncado. Flores com lobos do cálice iguais, 2,5-7 × 1-1,5 mm, deltoides, oblongos, glabros, ápice agudo a arredondado, com um tufo de tricomas castanhos no ápice, ciliados, glandulosos na face externa; pétalas 7-10 × 2-3 mm, clavadas ou lineares, ciliadas, ápice agudo ou arredondado, glandulosa na face externa; disco estaminal 1,5-2 mm diâm., pubescente; estames ca. 50, 5-6 mm compr.; hipanto $1-1,2 \times 0,7-0,9 \mathrm{~mm}$, liso, glabro ou tomentoso. Frutos 1-1,2 × 1,2-1,3 mm, lisos, globosos, atropurpúreos, glabros, verrucosos; sementes 1 ou 2, 8-7 × ca. $6 \mathrm{~cm}$, glandulosas.

Eugenia ligustrina apresenta ampla distribuição, ocorrendo do Caribe ao Brasil (Govaerts et al. 2008). Ocorre no Pará, Piauí, Ceará, Rio Grande do Norte, Paraíba, Pernambuco, Sergipe, Bahia, Minas Gerais, Rio de Janeiro, São Paulo, tendo o Paraná como limite sul de distribuição (Flora do Brasil 2020). Além destes estados, distribui-se também em Goiás (Faria 2010). B9, E6, E9, F3, F6, G5, G8/9, H9 e I8: na Mata Atlântica e na Caatinga. Coletada com flores e frutos de agosto a outubro.

Material selecionado - Água Quente, $13^{\circ} 15^{\prime} 50^{\prime \prime}$, 41 ${ }^{\circ} 51^{\prime}$ '04”W, nov. 2008 (fl.), Nascimento 635 (HUEFS); Belmonte, 1551'44”'S, 3852'58'W, s.d. (fr.), Belém 2471 (CEPEC); Caetité, $14^{\circ} 00^{\prime} 29^{\prime}$ 'S, 42³0'55”'W, maio 2008 (fl., fr.), Guedes et al. 14478 (ALCB); Coribe, 1335'10”'S, 44¹9'12”'W, abr. 2007 (fl.), Queiroz 12839 (CEPEC); Eunápolis, $16^{\circ} 25^{\prime} \mathrm{S}, 39^{\circ} 03^{\prime} \mathrm{W}$, mar. 1998 (fl.), Pereira 58 (CEPEC). Ilhéus, 1447'20”'S 3902'58”W, out. 1979 (fl.), Mori 12890 (CEPEC); Ipirá, 12²2'00”S, 3840'59”W, out. 1986 (fl., fr.), Queiroz 975 (HUEFS); Maracás, 16²5'S, 3903’W, nov. 1978 (fl.), Mori 11140 (CEPEC); Palmeiras, 12³6’S, 41 $27^{\prime} \mathrm{W}$, ago. 2007 (fl., fr.), Côrtes et al. 24 (HUEFS); Paulo Afonso, 09²8'59”S, 3804'59”W, jun. 2006 (fl.), Colaço 161

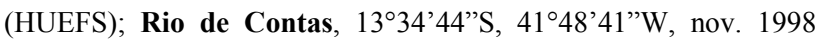
(fl.), Nascimento 90 (HUEFS); Salvador, 12 $58^{\prime} 16^{\prime \prime S}$, 38³0’39’W, nov. 2005 (fl.), Queiroz 1248 (HUEFS).

As folhas de Eugenia ligustrina são semelhantes às de E. longipedunculata Nied. e E. sulcata Spring ex Mart., que não ocorrem na Bahia. Eugenia ligustrina, no entanto, se diferencia dessas espécies por apresentar ramos jovens puberulentos ou pubescentes e hipanto e frutos não costados. Embora E. ligustrina tenha sido descrita com hipanto glabro (Berg 1857-1859; Faria 2010), ele é tomentoso na maioria dos espécimes da Bahia.

9. Eugenia mollicoma Mart. ex. O.Berg, Linnaea 27: 313. 1856.

Figuras 3, 6S-T e 11.

Arbustos 1-2 m alt.; ramos jovens castanhos, pilosos, com tricomas castanhos, os adultos acinzentados, puberulentos, com tricomas castanhos. Catafilos não vistos. Folhas com pecíolo 1,1-2,6 mm compr., canaliculado, glabro ou pubescente; lâmina 2,7-4,5 × 1,4-2,8 cm, membranácea, lanceolada, plana, pouco reticulada, glabra ou pubérula, glandulosa 


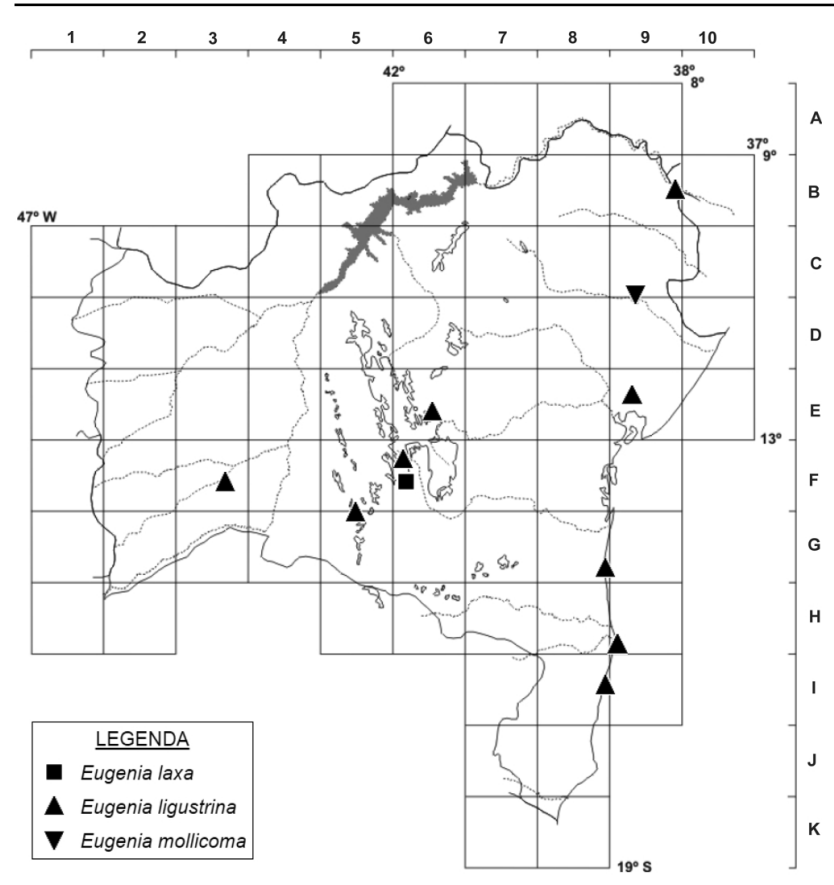

Figura 3. Mapa de distribuição de Eugenia laxa, E. ligustrina e E. mollicoma no estado da Bahia.

em ambas as faces (glândulas não visíveis a olho nu), ápice agudo, base cuneada, margens crenuladas; venação broquidódroma, nervura central levemente saliente na face adaxial, saliente na abaxial, glabra na face adaxial, com poucos tricomas na abaxial, 13-15 pares de nervuras secundárias, ascendentes, glabras, às vezes com poucos tricomas na face abaxial, nervura intarmarginal em arco irregular. Inflorescências com 2 flores; pedicelos 1,8-2 cm compr.; brácteas e bractéolas não vistas. Flores não vistas. Frutos 6,8-6,9 $\times$ 5,9-6,8 mm, globosos, lisos, verdes quando imaturos, com poucos tricomas, verrucosos; sementes não vistas.

Eugenia mollicoma é endêmica da Bahia. C9: em transição entre Mata Atlântica e Caatinga, encontrada com frutos em março.

Material examinado - Feira de Santana, 1056’57’'S, 38³8’13”W, mar. 2008 (fr.), Melo 5444 (HUEFS); s.l., s.d., Martius s.n. (M 01709854, foto!).

Eugenia mollicoma é caracterizada pelas folhas membranáceas, nervuras marginais em arco irregular e frutos lisos. Conhecida até então apenas pelo tipo, teve um material previamente identificado como E. uniflora tratado aqui como E. mollicoma por apresentar nervura central levemente saliente na face adaxial, frutos lisos, com tricomas esparsos.

10. Eugenia piresii Mattos, Loefgrenia 94: 3. 1989. Figuras 4 e 6U-V.

Árvores 2-3 m alt.; ramos jovens ferrugíneos, glabros. Catafilos $1-5 \times 1,5-4 \mathrm{~mm}$, oblongos ou elípticos, ciliados, glabros a levemente pilosos, ápice arredondado ou cuneado. Folhas com pecíolo 2-3 mm compr., canaliculado, glabro; lâmina 2,3-5,2 × 1-2,7 $\mathrm{cm}$, cartácea, obovada ou oblonga, glabra, plana, não reticulada, face abaxial pálida, glandulosa em ambas as faces, em maior abundância na adaxial (visíveis a olho nu somente na face abaxial), ápice obtuso, arredondado ou agudo e retuso, base aguda ou cuneada, margens revolutas, pouco onduladas; venação acródroma, nervura central sulcada na porção proximal da folha, impressa na adaxial e saliente na abaxial, glabra em ambas as faces, 10-17 pares de nervuras secundárias, ascendentes, glabras, geralmente visíveis somente na face adaxial, todas confluentes com a nervura intramarginal, 2 nervuras intramarginais de cada lado, a mais interna 1-2 $\mathrm{mm}$ da margem, a mais externa $0,5-$ $1 \mathrm{~mm}$ da margem. Inflorescências com 2-6 flores; pedicelos 2,1-3,5 cm, glabros; brácteas e bractéolas não vistas. Flores com lobos do cálice iguais, 3,2-4× 1,2-1,5 mm, oblongos ou deltoides, inteiros, glabros ou com poucos tricomas na face externa, ápice arredondado ou agudo, glândulas visíveis a olho nu; pétalas não vistas; disco estaminal ca. $3 \mathrm{~mm}$ compr., piloso; estames não vistos; hipanto não visto. Frutos ca. $8,4 \times 6 \mathrm{~mm}$, globosos, lisos, seríceos, tricomas castanhos; sementes 2, 3,3-3,4 × 4-4,5 mm, eglandulosas.

Eugenia piresii era considerada endêmica da Bahia (Flora do Brasil 2020), porém com a sinonimização de Stenocalyx gardnerianus O.Berg, cujo tipo foi coletado em Alagoas, a distribuição conhecida da espécie é ampliada. J8: em restingas no sul do estado. Coletada com frutos em outubro.

Material examinado - Prado, $17^{\circ} 16^{\prime} 59^{\prime}$ 'S, 39¹8'00'W, out. 2010 (fr), Thomas 9970 (CEPEC, RB).

Eugenia piresii é caracterizada pelas folhas obovadas ou oblongas com ápice obtuso e retuso, e pelos frutos seríceos.

\section{Eugenia pistaciifolia DC., Prodr. 3: 270. 1828.}

Figuras 4 e $6 \mathrm{~W}-\mathrm{Y}$.

Arbustos 0,8-2 m alt.; ramos jovens castanhos, glabros; ramos adultos branco-acinzentados, glabros. Catafilos 1-1,2 × 0,5-1 mm, côncavos, glabros, ápice arredondado, glândulas impressas na face externa. Folhas com pecíolo 2-4 $\mathrm{mm}$ compr., canaliculado, glabro ou com tricomas esparsos; lâmina $2-5,1 \times 0,8-$ $1,7 \mathrm{~cm}$, coriácea, discolores, lustrosa, lanceolada ou obovada, plana, não reticulada, glabra ou pubérula, glândulas não visíveis a olho nu, ápice acuminado, base arredondada, margens pouco revolutas; venação acródroma, nervura central impressa na face adaxial, saliente na abaxial, glabra ou pubérula na face adaxial, 8-10 pares de nervuras secundárias, ascendentes, às vezes imperceptíveis, glabras, confluentes com a nervura intramarginal distante $0,85-1,3 \mathrm{~mm}$ da margem. Inflorescências com 1-4 flores; pedicelos 0,4-1,2 cm compr., glabros; brácteas não vistas; bractéolas 1-1,2 $\mathrm{mm}$ compr., decíduas, glabras, ciliadas, ápice arredondado. Flores com lobos do cálice desiguais, os menores 1-1,7 × 1-1,6 mm, os maiores 2,5-3 × 1,4-2 mm, oblongos, ciliados, ápice arredondado, glabros, glândulas salientes na face 
externa; pétalas 3-4 × 2-4 $\mathrm{mm}$, orbiculares ou oblongas, ciliadas, reflexas, glabras, ápice arredondado, glandulosas; disco estaminal ca. $1 \mathrm{~mm}$ diâm., com tricomas esparsos; estames 37-50, 3-7 mm compr.; hipanto 1,3-1,3 × 1,1-1,5 mm, inteiro, glabro, glândulas salientes. Frutos 4-7 × 3-6 mm, lisos, globosos, verdes quando imaturos, glabros; semente 1 , ca. $0,5 \times 0,5$, eglandulosa.

Eugenia pistaciifolia foi registrada para Minas Gerais e Bahia. C6, D5, D6, E5/6, E/F5, E/F6, F6 e G5: em caatingas, campos rupestres e cerrados (Flora do Brasil 2020). As flores e frutos podem ser encontradas de setembro a abril.

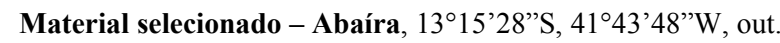
1996 (fl.), Queiroz 3839 (CEPEC); Barra do Mendes, 1209'03”S, 42 ${ }^{\circ} 01$ '03”'W, dez. 2009 (fl.), Melo et al. 7645 (HUEFS); Caetité, 1408'22”S, 42²7'48”'W, abr. 2004 (fl.), França et al. 3755

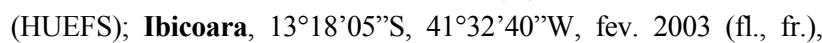

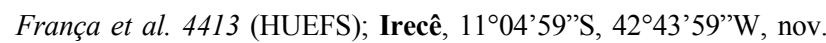

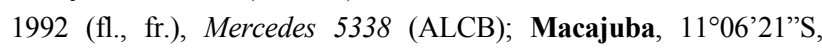
4243’22”W, mar. 1996 (fl., fr.), Conceição 2521 (CEPEC); Macaúbas, 1301'10”S, 4241'55W”, jan. 1997 (fl., fr.), Hatschbach 65938 (CEPEC, MBM); Morro do Chapéu, $11^{\circ} 33^{\prime} \mathrm{S}, 41^{\circ} 09^{\prime} \mathrm{W}$, nov. 1984 (fl., fr.), Noblick 3507 (HUEFS); Mucugê, 1300'24”'S, 4122'28”W, fev. 1997 (fl., fr.), Atkins PCD 5574 (HUEFS); Palmeiras, 12³8’34”S, 4133'57’'W, abr. 2012 (fl., fr.), Faria-Junior 2644 (UB); Piatã, 1303'00”'S, 4149'59’'W, mar. 1992 (fl., fr.),

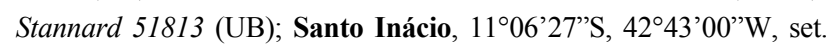
1999 (fl., fr.), Leite 29 (HUEFS); Seabra, 12²5’07’S, 4146’13”W,

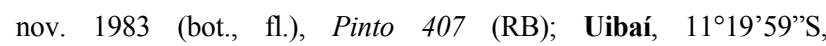
42॰07'59”W, mar. 1996 (fl., fr.), Atkins PCD 2487 (HUEFS);

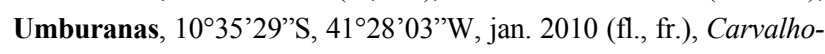

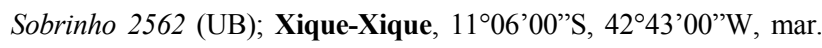
1996 (fl.), Conceição PCD 2521 (HUEFS).

Eugenia pistaciifolia pode ser reconhecida pelos catafilos glabros, folhas coriáceas, lustrosas, e flores totalmente glabras. Difere das demais espécies da seção Eugenia principalmente por não apresentar inflorescências auxotélicas.

12. Eugenia pitanga (O. Berg) Kiaersk., Enum. Myrt. Bras.: 155. 1893.

Figuras 4 e 8 A, B.

Arbustos ca. 0,7 m alt.; ramos jovens acastanhados, pilosos. Catafilos não vistos. Folhas com pecíolo 1,1-2,6 $\mathrm{mm}$ compr., canaliculado, pubescente ou piloso; lâmina 1,7-4,2 × 0,4-1 cm, estreito-elíptica ou oblonga, plana, reticulada, glabra na face adaxial, pubérulas na abaxial, glandulosa em ambas as faces (glândulas não visíveis a olho nu), ápice agudo ou obtuso, base aguda ou cuneada, margens levemente revolutas, às vezes com tricomas; venação broquidódroma, nervura central levemente saliente na face abaxial, glabra na adaxial, com tricomas esparsos na face abaxial, 11-22 pares de nervuras secundárias, ascendentes, glabras na face adaxial, com tricomas na adaxial, confluentes com a nervura intramarginal, 2 nervuras intramarginais, a mais interna $0,7-1 \mathrm{~mm}$ distante da margem, a mais

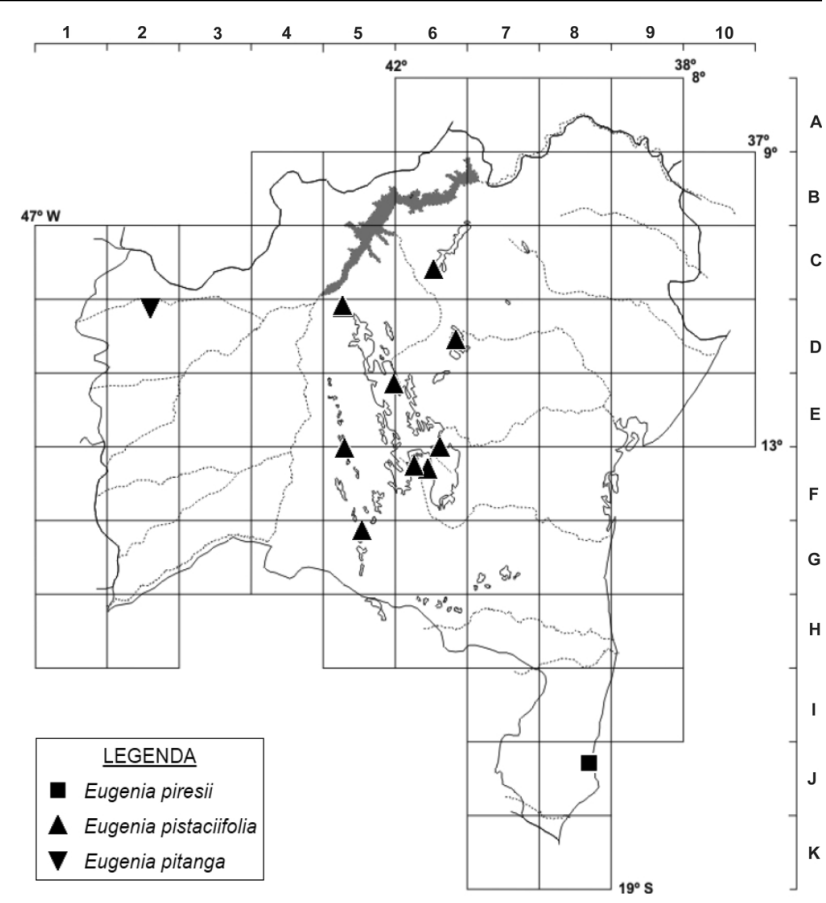

Figura 4. Mapa de distribuição de Eugenia piresii, E. pistaciifolia e E. pitanga no estado da Bahia.

externa 0,2-0,5 $\mathrm{mm}$ distante da margem. Inflorescências não vistas; pedicelos ca. 8,6 mm compr.; brácteas e bractéolas não vistas. Flores não vistas. Frutos ca. 1,6 × 1,6 cm, costados, globosos, verrucosos, atropurpúreos, glabros; semente 1, ca. 1,6 $\times 1,3 \mathrm{~cm}$, lisa, testa com poucos tricomas canescentes, glândulas não vistas.

Eugenia pitanga distribui-se do norte da Argentina ao nordeste do Brasil, sendo referida para o Rio Grande do Sul, Santa Catarina, Paraná, São Paulo, Rio de Janeiro, Minas Gerais, Mato Grosso, Mato Grosso do Sul e Bahia (Flora do Brasil 2020), nos pampas, campos rupestres e cerrados (Sobral 2003). D2: em cerrado, com frutos em novembro.

Material examinado - Formosa do Rio Preto, $11^{\circ} 06^{\prime} 22^{\prime \prime S}$, 45²4'11'W, nov. 1997 (fr.), Silva 3588 (UB).

Eugenia pitanga apresenta folhas estreito-elípticas ou oblongas, reticuladas, com nervura central levemente saliente na face adaxial e nervuras marginais e intramarginais presentes, inflorescências com pedicelos pequenos (ca. 8,5 mm compr.) e frutos costados (Sobral 2003).

13. Eugenia plicata Nied., Nat. Pflanzenfam. 3(abt. 7): 81. 1893.

Figuras 5 e $8 \mathrm{C}-\mathrm{E}$.

Árvores 6-17 m alt.; ramos jovens castanhos, puberulentos. Catafilos 2-3 $2-3 \mathrm{~mm}$, oblongos, puberulentos, ápice agudo ou arredondado. Folhas com pecíolo 0,5-1,4 mm compr., canaliculado, glabro; lâmina 2,4-7,5 × 0,6-3,5 cm, cartácea, lanceolada ou elíptica, plana, não reticulada, glabra na face adaxial, pubérulas na abaxial, glândulas impressas em ambas às faces (visíveis a olho nu somente na face abaxial), ápice acuminado ou agudo, base cuneada ou aguda, 
margens revolutas e pouco onduladas; venação acródroma, nervura central sulcada na face adaxial, saliente na abaxial, pubérula na face adaxial, 8-47 pares de nervuras secundárias, glabras, ascendentes, raramente curvadas, confluentes com a nervura intramarginal distante $0,5-1 \mathrm{~mm}$ da margem. Inflorescências com 1-4 flores; pedicelos 1,6-3,5 cm compr., glabros; brácteas e bractéolas não vistas. Flores com lobos do cálice desiguais, os menores 3-4 $\times 1-1,5 \mathrm{~mm}$, os maiores 5-5,1 × 1-1,5 mm, lineares, glabros, ciliados, ápice arredondado, glandulosos externamente; pétalas 3-5 × 2-4 $\mathrm{mm}$, rotundas, inteiras, glabras, ápice arredondado, glândulas não vistas; disco estaminal ca. $2 \mathrm{~mm}$ diâm., piloso; estames 76-86; hipanto 2-3 × 2-3 mm, inteiro, seríceo. Frutos e sementes não vistos.

Eugenia plicata está restrita à Mata Atlântica, no Rio de Janeiro, São Paulo e Bahia (Flora do Brasil 2020). G6, G8/9, $\mathrm{H8}$ e H9: em matas higrófilas. Foram coletadas com flores em fevereiro e setembro, e com frutos em outubro.

Material examinado - Almadina, $14^{\circ} 44^{\prime} 06^{\prime} \mathrm{S}, 39^{\circ} 41^{\prime} 46^{\prime} \mathrm{W}$, fev. 1997 (fl.), Jardim 1019 (MBM); Belmonte, 1551'47’S 3852'58”W, set. 1970 (fl.), Santos 1114 (CEPEC, RB); Mascote, 15³3'47’'S, 39¹8'09'W, out. 1988 (fr.), Matos-Silva 2558 (MBM, SP, UB); Uruçuca, $14^{\circ} 25^{\prime} 00^{\prime} \mathrm{S}, 39^{\circ} 01^{\prime} 00^{\prime \prime} \mathrm{W}$, s.d. (fr.), Thomas 8823 (CEPEC).

Eugenia plicata é facilmente reconhecida pelas folhas cartáceas com nervuras secundárias ascendentes, confluentes com a nervura intramarginal, apresentando ápice acuminado ou agudo e margens revolutas, e pelos lobos do cálice lineares e desiguais.

14. Eugenia potiraguensis K.Cout. \& M.Ibrahim, Phytotaxa 234(3): 222. 2015.

Figuras 5 e $8 \mathrm{~S}-\mathrm{V}$.

Árvores ca. $5 \mathrm{~m}$ alt.; ramos jovens acastanhados, glabros ou puberulentos, os adultos acinzentados, glabros. Catafilos 2-3 $\times$ 0,02-0,05 $\mathrm{mm}$, lineares, glabros ou puberulentos, ápice agudo ou arredondado, margens ciliadas. Folhas com pecíolo 3-6 mm compr., canaliculados, glabros; lâmina 2,9-8 × 0,8-2,25 cm, cartácea, lanceolada, plana, reticulada, glabra, glandulosa em ambas as faces (glândulas não visíveis a olho nu), ápice agudo, base cuneada, margens às vezes onduladas; venação acródroma, nervura central sulcada na face adaxial, saliente na abaxial, glabra em ambas as faces, 14-23 pares de nervuras secundárias, ascendentes, glabras, pouco visíveis na face abaxial, confluentes com a nervura intramarginal distante 0,4-1 $\mathrm{mm}$ da margem. Inflorescências com 2-4 flores; pedicelos 1,7-2,7 cm compr., glabros; brácteas e bractéolas não vistas. Flores com lobos do cálice iguais, 4-5,1 × 1,2-1,9 mm, deltoides ou lineares, ápice agudo ou arredondado, glabros, ciliados, glandulosos na face externa; pétalas não vistas; disco estaminal ca. 3,2 mm diâm., piloso; estames não vistos; hipanto 1,7-2,2 $\times$ 1,8-1,9 $\mathrm{mm}$, liso, pubescente, eglanduloso. Frutos $1-1,5 \times 0,6-1 \mathrm{~cm}$, lisos, globosos, achatados transversalmente, puberulentos, glândulas salientes; semente 1 , ca. $7,3 \times 3,7 \mathrm{~mm}$, globosa, eglandulosa.

Eugenia potiraguensis é referida apenas para Bahia. E8 e H8: em Mata Atlântica, frutificando de junho a setembro.

Material examinado - Cachoeira, $12^{\circ} 32^{\prime} 00^{\prime \prime} \mathrm{S}, 39^{\circ} 05^{\prime} 00^{\prime \prime} \mathrm{W}$, set. 1980 (fr.), Grupo Pedra do Cavalo 781 (ALCB, CEPEC); Potiraguá, 1542’12”'S, 39³4’32”'W, jun. 2004 (fr.), Fiaschi et al. 2287 (CEPEC).

Eugenia potiraguensis se assemelha a E. plicata pela forma, tamanho e textura das folhas. Suas folhas, no entanto, possuem glândulas visíveis na face abaxial e pecíolo mais longo ( $\geq 3 \mathrm{~mm}$ vs. $\leq 1,4 \mathrm{~mm}$ ). Além disso, o disco estaminal é maior em E. potiraguensis (ca. 3,2 mm vs. ca. 2 mm diâm.).

\section{Eugenia sessilifolia DC., Prodr. 3: 263. 1828.}

Figuras 5.

Arbustos ca. $2 \mathrm{~m}$ alt.; ramos jovens castanhos, glabros, os adultos acinzentados. Catafilos não vistos. Folhas sésseis; lâmina 2,9-6,6 × 1,6-2,5, membranácea, lanceolada, plana, não reticulada, glabra, glandulosa em ambas as faces (glândulas não visíveis a olho nu), ápice agudo, base truncada ou subcordada, margens levemente revolutas; venação acródroma, nervura central sulcada na face adaxial, saliente na abaxial, glabra em ambas as faces, 18-26 pares de nervuras secundárias, subascendentes, glabras, confluentes com a nervura intramarginal, 2 nervuras intramarginais de cada lado, a mais interna distante 1,6-1,8 $\mathrm{mm}$ da margem, a mais externa menos visível, distante 0,4-0,7 mm. Inflorescências com 1-4 flores; pedicelos 1,7-2,1 cm, glabros; brácteas e bractéolas não vistas. Flores não vistas. Frutos ca. $1 \times 1$, não costados, globosos, verrucosos; sementes não vistas.

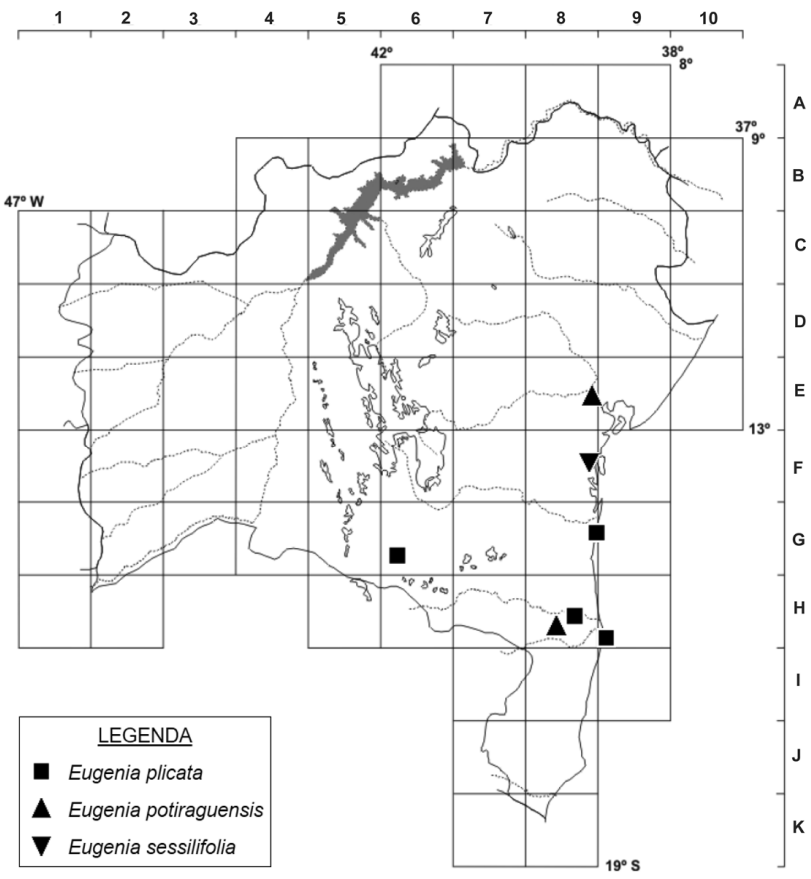

Figura 5. Mapa de distribuição de Eugenia plicata, E. potiraguensis e E. sessilifolia no estado da Bahia. 


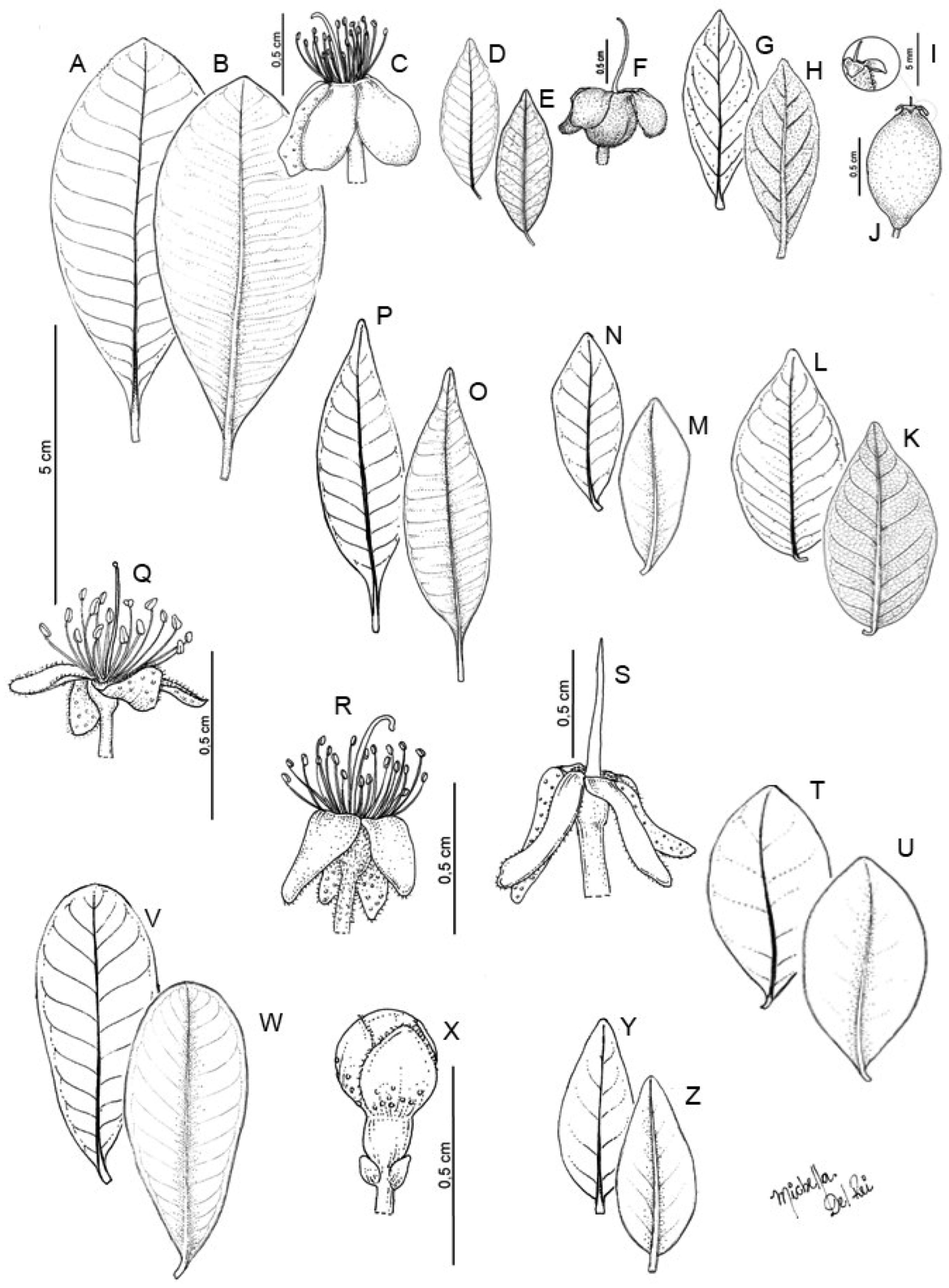

Figura 6. A-C. Eugenia brasiliensis (Matos-Silva 4501): A- folha, face adaxial; B- folha, face abaxial; C- flor. D-F. E. caatingicola (Queiroz 12045): D- folha, face adaxial; E- folha, face abaxial; F- fruto imaturo. G-J. E. duarteana (Carvalho-Sobrinho 3214): G- folha, face adaxial; H- folha, face abaxial; I- detalhe do ápice do fruto; J- fruto. K, L. E. dysenterica (Guedes 14068): K- folha, face abaxial; L- folha, face adaxial. M-S. E. ligustrina (M, N, Q, R- Nascimento 90; O, P, S- Mori 12890): M-P- folhas, mostrando variação; Q-S- variação das flores. T, U. E. mollicoma (Melo 5444): T- folha, face adaxial; U- folha, face abaxial. V, W. E. piresii (Thomas 9970): V- folha, face adaxial; W- folha, face abaxial. X-Z. E. pistaciifolia (França 4413): X- botão; Y- folha, face adaxial; Z- folha, face abaxial. As folhas estão na mesma escala (referência de A e B). 
Eugenia sessilifolia é conhecida apenas para Bahia. F8: Mata Atlântica (Flora do Brasil 2020), com frutos em dezembro.

Material examinado - "Habitat inter sepes atque in silvis caeduis prope Camamú et Ilheos in prov. Bahiensi", s.d., Martius s.n. (holótipo M, foto!).

Difere das demais espécies da seção por apresentar folhas membranáceas e sésseis, com base truncada ou subcordada. Conhecida apenas pelo tipo e por um material depositado no herbário NY. A descrição aqui apresentada teve como base a análise e mensuração da imagem do tipo (JSTOR 2013) e nas descrições de Candolle (1828) e Berg (1857-1859).

16. Eugenia subreticulata Glaz., Bull. Soc. Bot. France 54(Mem. 3c): 233. 1908.

Figuras 7 e $8 \mathrm{~F}-\mathrm{H}$.

Árvores ca. $7 \mathrm{~m}$ alt.; ramos jovens acastanhados, puberulentos, tricomas alvos. Catafilos não vistos. Folhas com pecíolo $8-13 \mathrm{~mm}$ compr., canaliculado, glabro; lâmina 3,5-8 × 1-2,4 cm, cartácea, lanceolada ou elíptica, plana, reticulada, glabra ou pubrulenta, glândulas visíveis a olho nu apenas na face abaxial, ápice acuminado ou agudo, base cuneada, margens inteiras; venação broquidódroma, nervura central sulcada na face adaxial, saliente na abaxial, glabra na face adaxial, com poucos tricomas na abaxial, 18-25 pares de nervuras secundárias, glabras, ascendentes, salientes em ambas as faces, confluentes com a nervura intramarginal distante 1-2 $\mathrm{mm}$ da margem. Inflorescências com 2 flores; pedicelos $1,5-3 \mathrm{~cm}$ compr., pilosos ou pubescentes; brácteas e bractéolas não vistas. Flores com lobos do cálice iguais, 5-7 $\times$ 1,5-2 mm, deltoides ou oblongos, ciliados, ápice agudo ou arredondado, piloso, tricomas alvos, glândulas visíveis a olho nu externamente; pétalas não vistas; disco estaminal ca. 4 mm diâm., glabro; estames não vistos. Frutos ca. $9 \times 8 \mathrm{~mm}$, lisos, globosos, verrucosos, com tricomas esparsos próximos aos lobos do cálice; sementes não vistas.

Eugenia subreticulata ocorre em floresta ombrófila de Minas Gerais e Bahia (Flora do Brasil 2020). E8: único registro coletado com fruto em dezembro.

Material examinado - Cachoeira, $12^{\circ} 32^{\prime} \mathrm{S}, 39^{\circ} 05^{\prime} \mathrm{W}$, dez. 1980 (fr.), Grupo Pedra do Cavalo 956 (ALCB, CEPEC, HUFS, RB).

Eugenia subreticulata é caracterizada pelas folhas estreitas, reticuladas, nervuras secundárias salientes em ambas as faces, pecíolos ( $\geq 1,5 \mathrm{~cm}$ compr.) e lobos do cálice longos ( $\geq 5 \mathrm{~mm}$ compr.), com glândulas visíveis a olho nu nos lobos do cálice.

\section{Eugenia uniflora L., Sp. Pl. 1: 470. 1753.}

\section{Figuras 7 e 8I-L.}

Árvores ou arbustos 2-4 m alt.; ramos jovens castanhos, glabros, os adultos acinzentados. Catafilos 1-3 × 1,1-2 mm, côncavos, glabros ou pilosos, ápice agudo ou arredondado. Folhas com pecíolo 1,4-3,8 $\times$ $0,6-0,9 \mathrm{~mm}$, canaliculados, puberulentos; lâmina $2-5,5$ $\times 1,4-4 \mathrm{~mm}$, cartácea a coriácea, lanceolada, ovada, elíptica, plana, reticulada, glabra, glândulas sulcadas em ambas as faces (não visíveis a olho nu), ápice agudo, acuminado ou obtuso, base arredondada, cuneada ou aguda, margens levemente revolutas; venação broquidódroma, nervura central sulcada no terço proximal, impressa no restante da face adaxial e saliente na face abaxial, glabra em ambas as faces, 915 pares de nervuras secundárias, ascendentes, glabras, nervura intramarginal formada pelos arcos das nervuras secundárias. Inflorescências com 2-4 flores; pedicelos 1,5-3 cm compr.; brácteas não vistas; bractéolas ausentes. Flores com lobos do cálice iguais, 3,3-3,9 $\times$ 1,8-2,8 $\mathrm{mm}$, oblongos ou deltoides, ciliados, ápice arredondado ou agudo, com tricomas esparsos, glândulas na face externa; pétalas 7-8 × 2-3,6 mm, espatuladas ou clavadas, ciliadas, glabras, ápice arredondado, eglandulosas; disco estaminal 2-2.7 mm, pubescente; estames 58-65, 3-6 mm compr.; hipanto 1,2-1,6 × 1,2-1,4, costado, glabro, glanduloso. Frutos $1-1,5 \times 1,1-1,3 \mathrm{~mm}$, globosos, costados, verrucosos, verdes passando a vermelho-alaranjados quando maduros, glandulosos; sementes $2-4,7,1-7,7 \times 5-7,3$ $\mathrm{mm}$, testa com poucos tricomas.

Eugenia uniflora distribui-se do norte do Uruguai e Argentina ao Brasil (Legrand \& Klein 1969), do Rio Grande do Sul à Bahia, em cerrados, matas ciliares, florestas perenifólias, florestas estacionais semideciduais, florestas ombrófilas, florestas ombrófilas mistas e restingas (Flora do Brasil 2020). D4, E8, E9, F6, F8, G8, G8 e J8: em florestas estacionais, caatingas, matas higrófilas, restingas e áreas urbanas. Floresce de julho a fevereiro e frutifica de novembro a fevereiro.

Material selecionado - Abaíra, 1316'00'S, 41 ${ }^{\circ} 52^{\prime} 59^{\prime}$ 'W, fev. 1992 (fl.), Stannard 51682 (HUEFS, UB); Almadina, 1442’19”S, 39॰38'14”W, dez. 1983 (fl.), Silva 96 (CEPEC); Amargosa,

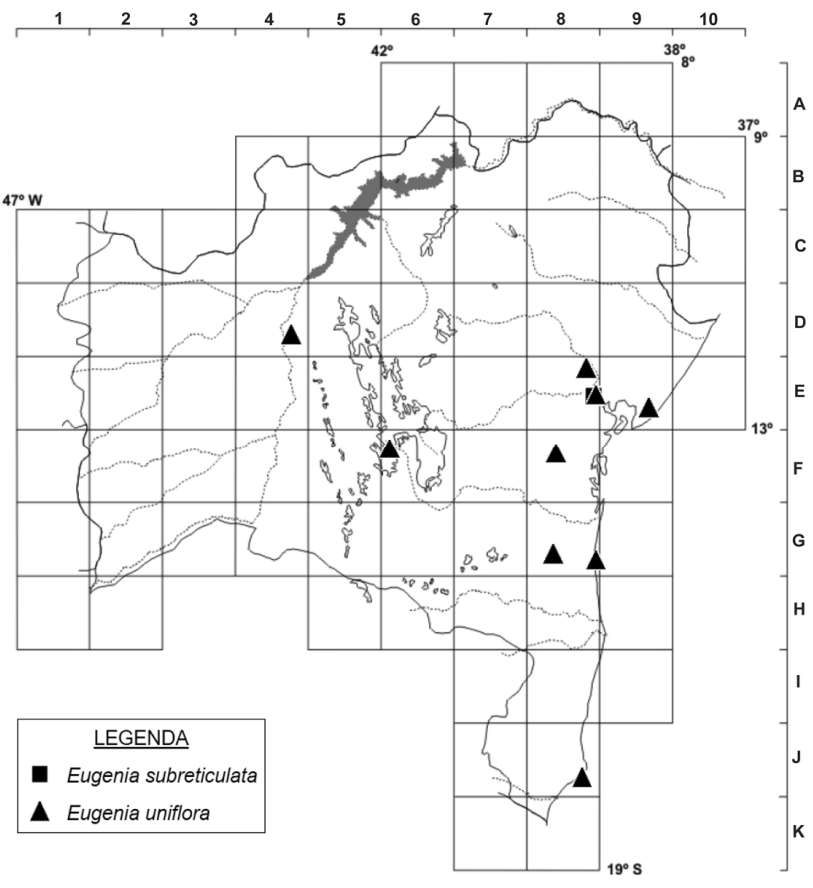

Figura 7. Mapa de distribuição de Eugenia subreticulata e E. uniflora no estado da Bahia. 

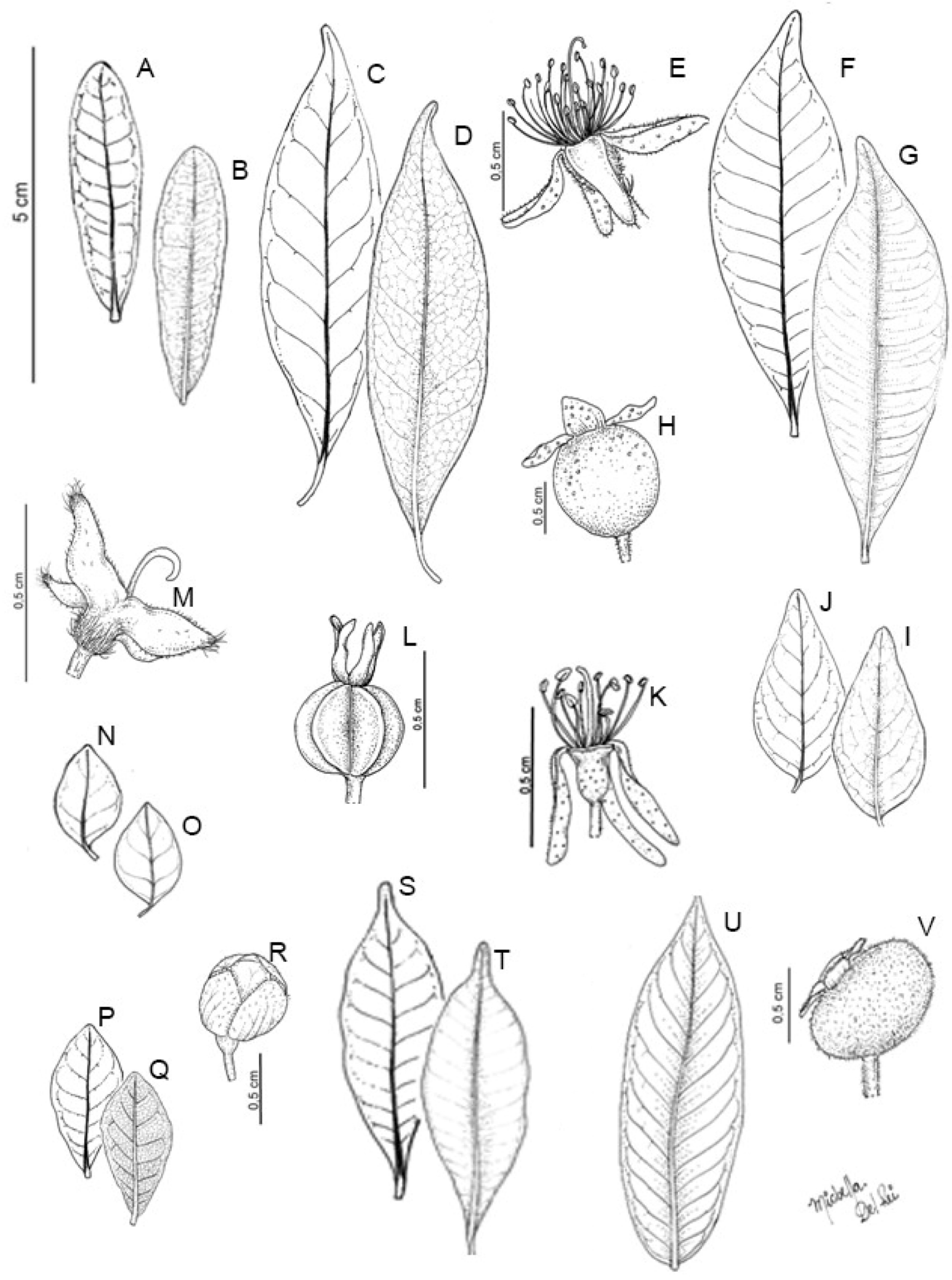

Figura 8. A, B. Eugenia pitanga (Silva 3588): A- folha, face adaxial; B- folha, face abaxial. C-E. E. plicata (Santos 1114): C-;folha, face adaxial; D- folha, face abaxial; E- flor. F-H. E. subreticulata (Grupo Pedra do Cavalo 956): F- folha, face adaxial; G- folha, face abaxial; H- fruto. I-L. E. uniflora (Matos 972): I- folha, face abaxial; J- folha, face adaxial; K- flor; L- fruto. M-O. E. funchiana (Harley 16431): M- flor; N- folha, face adaxial; O- folha, face abaxial. P-R. E. coccinea (Carvalho 1983): P- folha, face adaxial; Q- folha, face abaxial; R- botão floral. S-V. E. potiraguensis (Grupo Pedra do Cavalo 781): S- folha, face adaxial; T- folha, face abaxial; U- folha, face abaxial; V- fruto. As folhas estão na mesma escala (referência de A e B). 


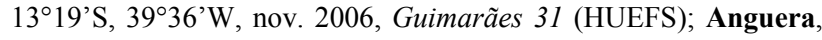
1209'42”S, 39¹1'02”W, nov. 2006 (fl., fr.), Cardoso 1453 (HUEFS); Camaçari, 1241'51’'S, 38¹9'27’'W, fev. 2004 (fl., fr.),

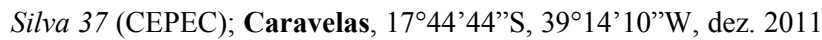
(fl.), Matos 972 (HUEFS); Ilhéus, 144'20”'S, 3902'58’W, nov. 1987 (fl., fr.), Hage 2203 (CEPEC, RB, SP); Mata de São João, 12॰31'49”S, 38॰17'57'W, jul. 2002 (Fl.), Medeiros 189 (RB); Morpará, $11^{\circ} 42^{\prime} 06^{\prime}$ 'S, 4313'52”W, jun. 2007 (est.), Conceição 2244 (HUEFS).

Eugenia uniflora pode ser reconhecida pelos ramos e hipanto glabros e frutos costados, bem como pelas folhas lanceoladas, ovadas ou elípticas, glabras na face adaxial, com nervura central não saliente na face adaxial e ausência de nervuras intramarginais e marginais. Conhecida como pitanga, é bastante cultivada em razão de suas propriedades medicinais e frutos comestíveis (Souza \& Morim 2008). Na Bahia, a maior parte dos materiais nos herbários foi coletada em áreas antropizadas, sugerindo que a ocorrência e distribuição desta espécie no estado seja resultado de ação antrópica.

\section{AGRADECIMENTOS}

Karoline Coutinho de Santana agradece ao Programa de Pós-graduação em Botânica da UEFS, à CAPES (coordenação de aperfeiçoamento de pessoal de nível superior), pela bolsa, aos projetos Flora da Bahia e Protax, pelo financiamento de expedições, e aos revisores pelas valiosas contribuições.

\section{REFERÊNCIAS}

Berg, O. 1857-1859. Myrtaceae. In: C.F.P. Martius (ed.), Flora Brasiliensis. Vol. 14, pars 1. F. Fleischer, Monachii \& Lipsiae, p. $430-465$.

Briggs, B.G. \& Johnson, L.A.S. 1979. Evolution in Myrtaceae evidence from inflorescence 14 structure. Proc. Linn. Soc. N. S. $W ., 102(4): 158-256$.

Candolle, A.P. 1828. Myrtaceae. Prodromus Systematis Naturalis Regni Vegetabilis. Vol. 3. Treuttel \& Würtz, Paris, p. 207-296.

Faria, J.E.Q. 2010. O gênero Eugenia L. (Myrtaceae) nos estados de Goiás e Tocantins, Brasil. Dissertação de Mestrado. Universidade de Brasília, Brasília.
Flora do Brasil 2020, em construção. Eugenia. Jardim Botânico do Rio. Disponível em: <http://floradobrasil.jbrj.gov.br/reflora/ floradobrasi1/FB25834>. Acesso em: 14 dezembro 2017.

Govaerts, R.; Sobral, M.; Ashton, P; Barrie, F.; Holst, B.K.; Lamdrum, L.R.; Matsumoto, K; Mazine, F.F.; Lughadha, E.M.; Proença, C.; Soares-Silva, L.H.; Wilson, P.G. \& Lucas, E. 2008. World Checkilist of Myrtaceae. Royal Botanic Gardens, Kew.

JSTOR 2013. Global Plants. Disponível em: http://plants.jstor.org/. Acesso em: 10 maio 2013.

Legrand, C.D. \& Klein, R.M. 1969. Mirtáceas. In: P.R. Reitz (ed.), Flora Ilustrada Catarinense. Vol. 23. Herbário Barbosa Rodrigues, Itajaí, p. 1-876.

Lorenzi, H.; Sartori, S.F.; Bacher, L.B. \& Lacerda, M. 2006. Frutas Brasileiras e Exóticas Cultivadas (de Consumo in Natura). Instituto Plantarum de Estudos da Flora, Nova Odessa, p. $178-190$.

Lucas, E.J.; Harris, S.A.; Mazine, F.F.; Belsham, S.R.; Nic Lughadha, E.M.; Telford, A.; Gasson, P.E. \& Chase, M.W. 2007. Suprageneric phylogenetics of Myrteae, the generically richest tribe in Myrtaceae (Myrtales). Taxon 56: 1105-1128.

Mazine, F.F.; Souza, V.C.; Sobral, M.; Forest, F. \& Lucas, E. 2014. A preliminar phylogenetic analysis of Eugenia (Myrtaceae: Myrteae), with a focus on neotropical species. Kew Bulletin 69(2): 1-14.

Mazine, F.F.; Bünger, M.O.; Faria, J.E.Q.; Lucas, E. \& Souza, V.C. 2016. Sections in Eugenia (Myrteae, Myrtaceae): nomenclatural notes and a key. Phytotaxa. 289(3): 225-236.

Oliveira, M.I.U; Funch, L.S. \& Landrum, L.R. 2012. Flora da Bahia: Campomanesia (Myrtaceae). Sitientibus série Ciências Biológicas 12(1): 91- 107 .

Sobral, M. 2003. A família Myrtaceae no Rio Grande do Sul. Editora Unisinos, São Leopoldo, p. 41-48.

Souza, M.C. \& Morim, M.P. 2008. Subtribos Eugeniinae O. Berg e Myrtinae O. Berg (Myrtaceae) na restinga da Marambaia, RJ, Brasil. Acta Botanica Brasilica 22: 652-683.

WCSP 2017. World Checklist of Selected Plant Families. Disponível em: <apps.kew.org/wcsp/>. Acessado em: dez. 2017.

Wilson, P.G. 2011. Myrtaceae. In: K. Kubitzki (ed.), The Families and Genera of Vascular Plants. Volume X. Flowering plants Eudicots: Sapindales, Cucurbitales, Myrtaceae. SpringerVerlag, p. 212-271.

Wilson, P.G.; O'Brien, M.M.; Heslewood, M.M. \& Quinn, C.J. 2005. Relationships within Myrtaceae sensu lato based on a matK phylogeny. Plant Systematics and Evolution. 251: $3-19$.

\section{LISTA DE EXSICATAS}

Alunos de Sistemática, s.n. HUEFS 45307 (17); Amorim, A.M. 1431 (1), 2511 (8); Araújo, A. 131 (5); Araújo-Nobrega, M. 26 (11); Arbo, M.M. 5338 (11); Atkins, S. PCD 2487, PCD 5574, PCD 5586 (11); Bautista, H.P. 3259 (5); Belém, R.P. 2471 , 2772 (8); Cardoso, D.B.O.S 216 (5), 1453 (17); Carvalho A.M. 117, 211 (1), 1973 (8), 1987 (9); Carvalho, G.M. s.n. CEPEC 140225 (1); CarvalhoSobrinho, J. 2562 (11), 3214 (4); Coloço, M. 161 (8); Conceição, C.C. 2244 (17), PCD 2521 (11); Correia, C. 268 (5); Côrtes, A.L. 24 (8); Curran, H.M. 328 (17); Dânaso, V. 5, (5); Eupunino, A. 270 (1); Faria-Junior, J.E.Q. 1894, 2643, 2644, 2645, 4420, 5864 (11); Fiaschi, P. 2287 (14); França, F. 2191 (17), 3755, 4413 (11); Ferreira, M.H.S. 28 (17); Forza, R.C. 1371 (8); Funch, R. 512 (11); Ganev, W. 875, 1038, 1159 (5), 1400, 1420 (11), 2026 (5); Glocker, C.E.F. 69bis (17); Guimarães, O.S. 31 (17); Grupo Pedra do Cavalo 718 (14), 956 (16); Guare, F.S. s.n. ALCB 75137 (11); Guedes, M.L. 9438 (1), 10299, 10925, 11413, 13339, 13419, 13433, 13718, 14068, 14473 (5), 14478 (8), 16125 (11) 16651 (5); Hage, J.L. 2203 (17); Harley, R.M. 16431 (6), 19017 (11), 28261, 54664 (5); Hatschbach, G. 
44179 (5), 50736 (1), 65938 (11) 78707 (5); Ibrahim, M. 53, 97 (11); Irwin, H.S. 30830 (11); Jardim, J.G. 1019 (13), 2284 (1); Jesus, J.A. 513 (8); Kral, R. 75565 (11); Lacerda, V.D. 235(1); Leite, K.R.B. 29 (11); Leite, M.P. 56 (17); Lima, D.P. 12715 (1); Martius, C.F.P. s.n. M 0137751 (7), s.n. M 01709854 (9); Matos, E.N. 972 (17); Matos-Silva, L.A. 1281, 1793 (1), 2558 (13), 4173 (17), 4501 (1), 78707 (5); Mello, E. 5413 (17), 5444 (9), 7645 (11), 8371, 8831 (2), 10533, 10635, 11372(8); Melo-Silva, R. 2793 (11); Mendes, M.S. 517 (5); Mercedes, M. 5338 (11); Moraes, M.V. 125 (17); Mori, S.A. 11140, 12890 (8), 13380 (11); Nascimento, F.H.F. 90, 635 (8); Noblick, L.R. 3507 (11); Nunes, M.S. 31 (5); Nunes, M.T.G 74 (1); Nunes, T.S. 45 (5), 129 (11); Oliveira, R.P. 60 (11); Paula-Souza, J. 9248 , 9243 (5); Passos Júnior, L.A. PCD 5546 (11); Pereira, P.A. 58 (8); Pereira, R.N.S. 94 (4); Pinto, G.C.P. 86 (1); Proença, C. 1768 (5); Queiroz, E.P. 1248 (8); Queiroz, L.P. 975 (8), 1248 (8), 8049 (11), 9849 (4), 12045 (2), 12839 (8), PCD 3839 (11); Ribeiro, T. 316 (5); Roque, N. 2488 (8); Sano, P.T. CFCR 14497 (11); Sant'Ana, S.C. 115 (8); Santos, A.S. 4 (17); Santos, F.S. 98 (1); Santos, T.S. 1114 (13), 1758 (8), 4511 (17); Silva, L.A.M. 96 (17), 2588 (8); Silva, C.A. Pau Brasil 26 (1) Silva, M.A. 3588 (12), 3592,3596 (5); Silva, P.E.N. 77 (5); Sobrinho, J.C. 3214 (4); Souza, E.R. 589 (11); Souza, V.C. 5435 (11); Stadnik, A. 74, 150, 180 (11), 223 , 324 (5); Stannard, B. 51682 (17), 51813 (11); Thomas, W.W. 8823 (13), 9970 (10), 12678, 13866 (1), 13917 (8); Thomas, M.B. 507 (17); Vieira, B.F. 56 (11); Vieira, R.F. 2056 (5); Violatii, L.G. 63 (5); Voeks, R. 189, 610 (17); Xavier, A.B. 255 (5). 